VOL. 01 NO. 01, JUNE 2019

\title{
Dictions Used by Religious Leaders in The Diffusion of Extension Forestry Program in Probolinggo Municipal
}

\author{
TIRMIDI \\ Universitas Nurul Jadid \\ tirmidi1973@gmail.com
}

\begin{abstract}
An element identified as one of key points in the success of diffusion of extension forestry program, namely greening up to 6.000 hectares, was the involvement of religious leaders, especially on communicating the program to the villagers. This paper aims to describe, analyze, and interpret the dictions used by religious leaders in the program. Through a qualitative research designed in phenomenological approach, especially at naturalistic paradigm, the research found that instead of using that of semantically classified as environmental and social terms, the religous leaders preferred using that of economical terms, namely financial benefits of planting trees for the local farmers. A proposition filed from this research is: communication of innovation in the field of extention forestry program will be accepted widely and quickly by villagers when the dictions used are words that emphasize on financial benefits which might be obtained from the program.
\end{abstract}

Keywords: diction, environmental discourse, diffusion of innovation

\section{INTRODUCTION}

The large scale of Indonesian forest degradation has lowered down the quality of life of our nation and even it also endagered the existence of Indonesian citizens (anonymous, 2006; Wibowo, 2006, Baplan in Agus, Noordwijk, Rahayu, 2004). In the objective of mitigating the impacts of forest degradation, Indonesian government, on March 2003, issued a policy named National Act on Rehabilitating Critical Lands and Forests (Gerakan Nasional Rehabilitasi Hutan dan Lahan Kritis). The similar policy was also issued in 1946. Based on the evaluation of the Board of Research and development and CIFOR (Center for International Forestry Research), however, the programs are titled as failed (Wibowo, 2006:72-76). The abovementioned agencies concluded that, in terms of technical and financial affordability, there was no problem found. The problems, as the matter of facts, were found in the area of institutional aspects, especially on the absence of acceptable social institution for the community. In other words, the program needs motivators, or accellarators who are publicly accepted to diffuse the program deeply in the hearts of the persons in the community.

In correlation to the needs of motivators or accellerators, it was a great fortune that there was a success story from religious leaders, who are also local leaders, in Madurese community in Probolinggo municipal, of how to encourage and to maintain spirits of the community in the process of rehabilitation and reforestratiion program. the local leaders succeeded to lead the community on planting trees of sengon (paraserianthes facataria) in the total area of 6.000 hectares in lands lied on two subdistrics: Krucil and Tiris, in Probolinggo municipal. Among the 6.000 hectares, moreover, there has been 132.6 hectares that obtained certificate of sustainable forest management from Forest Stewardship Council of UK. The success, therefore, might be taken as model on program replication in different area in Indonesia. The success story, in addition, attracts some inquires to the writer, especially on the dictions used by the religious (local) leaders in communicating the innovation (program) to villagers who are Madurese community in Probolinggo municipal. 


\section{VOL. 01 NO. 01, JUNE 2019}

Before analyzing the dictions used in communication of innovation, we need to identify influencing variables in this field. Wejnert (2002) proposes that there are three major influencing variables in communication of innovation, namely the characteristics of innovaton, the characteristics of innovatiors, and the characteristics of environment. Among these three characteristics, Wejnert (2002) notes that the study of the characteristics of innovators remains the minority. This might be caused, as Wejnert's (2002) additional notes, by difficulties to trace the stories back to the time of initiation, and treatment upon confidential documents.

Furthermore, still on the influencing variables, Rogers (1983) proposes that there are at least four variables that give major influence on the success of diffusion of innovation, namely: the characteristics of the innovation itself, the change agent, the sources of information, and early adopters. Based on these variables, Rogers proposes that information is an important factor in influencing the clients so that they come into a conclusion to participate or to reject the innovation (Rogers and Shoemaker, 1971). It means that access to information take an important role in the success of diffusion. Glendinning, Mahapatra, Mitchell (2001) give evidence on this concern.

Glendinning, et.al (2001), who conduct research on the success of extension forestry program in India, state that contact with change agent, which mediates agency and clients, has a great influence in delivering community to accept or reject the new idea, in this case is extension forestry program. Glendinning, et.al (2001) give additional note that this condition is driven by intermediary functions owned by the change agent, namely: (1) establishing the need for change, (2) establishing relationships with clients, (3) diagnosing problem, (4) fostering clients' desire to change, (5) translating the desire into action for change, (6) establishing change and anticipating discontinuation, and (7) building client self-relience. Hence, it is clearer that with these seven roles, change agent has an obviously very significant role on the success of the spread and the adoption of innovation or new idea.

In communication new ideas, moreover, Rogers and Shoemaker's (1971) concept of change agent which has similar concept to that of Geertz's (1960) concept of culture broker, should be wise in choosing words when the communicate to clients (Wozniak, 2003; Wendt, 1994; Levesque, 2004; Honig-Haftel, 1996; Kuttner, 2003; Pittaway, Rivera, Murphy, 2005, Carman, 2008; Humprey, 1998). This brief article is intended to describe, analyze, and interpret dictions used by religious leaders in communicating the extension forestry program in Probolinggo municipal from its initiation phase to the time of international ecolabel certification registration.

\section{RESEARCH METHOD AND RESULTS}

To reach these goals, a research on qualitative method and design was employed by using phenomenological approach on naturalistic inquiry paradigm. The research was done in the subdistricts of Krucil and Tiris of Probolinggo Municipal where the initiation of the program was located. The subjects of the study were classified into three categories, namely key informants, subjects, and supporting informants. Primary data were obtained from in-depth interviews and field observations; secondary data, in addition, were got from documents in the forms of reports, daily newspapers, etc. The data were then analysed through inductivegenerative-constructive-subjective end procedure.

The results show that the development of extension forestry program in Probolinggo municipal took three years (2003-2005) in the process of convincing public; two years (20052006) of planting activities; and two years (2006-2007) of convincing public to engage in international ecolabel certification program. The religious leader could not directly come into planting activities for the program were held in the lands owned by a lot of people. Hence the 
VOL. 01 NO. 01, JUNE 2019

reigious leader should persuade, and convince as well, the owner of the lands. Matters that should be convinced were mostly more on guarantee that the program was on the landowner's favor. As presented above, it took three years for religous leader to convice the owners of the lands. Once the owners of the lands were convinced, the religious leader only needed two years to plant lands amounting 6.000 hectars with woods. The last, as the impact, there was no serious hindrance on convincing people to join international label certification program.

List of words used by religious leader from initiation phase to international ecolabel certification registration phase is as presented in table 1.

Table 1. List of Words Used by Religious Leader

\begin{tabular}{|c|c|c|c|}
\hline \multirow[t]{2}{*}{ No. } & \multirow[t]{2}{*}{ Phase } & \multicolumn{2}{|c|}{ Dictions } \\
\hline & & in Madurese & in English \\
\hline \multirow[t]{10}{*}{1} & \multirow[t]{10}{*}{ Initiation phase (2003-2005) } & $\begin{array}{l}\text { Tanembhang bendung } \\
\text { sabenah }\end{array}$ & $\begin{array}{lr}\text { compared } & \text { to } \\
\text { condition when the } \\
\text { lands are left } \\
\text { unplanted }\end{array}$ \\
\hline & & $\begin{array}{l}\text { Ma'le ta' mesken } \\
\text { salanjenga }\end{array}$ & $\begin{array}{l}\text { to avoid endless } \\
\text { poverty }\end{array}$ \\
\hline & & Ta' rogi napah & nothing to loose \\
\hline & & Paroan & $\begin{array}{l}\text { (in) profit sharing } \\
\text { system }\end{array}$ \\
\hline & & $\begin{array}{l}\text { Tanembhang ngoli } k a \\
\text { Sorbajah }\end{array}$ & $\begin{array}{l}\text { compared to that of } \\
\text { being coolies in } \\
\text { Surabaya }\end{array}$ \\
\hline & & $\begin{array}{l}\text { Bisa melleh sepeda } \\
\text { montor }\end{array}$ & $\begin{array}{l}\text { to make motorcyle } \\
\text { (and other tertiary } \\
\text { needs) affordable }\end{array}$ \\
\hline & & Pakanah sapeh & for cattle fodder \\
\hline & & Bisa abangun romanah & $\begin{array}{l}\text { to be able build } \\
\text { (their) house }\end{array}$ \\
\hline & & Anak bisa asakola teggih & $\begin{array}{l}\text { be able to send (their) } \\
\text { children to higher } \\
\text { education }\end{array}$ \\
\hline & & Onggha hajji & $\begin{array}{ll}\begin{array}{l}\text { may go for } \\
\text { pilgrimage }\end{array} & \\
\end{array}$ \\
\hline \multirow[t]{4}{*}{2} & \multirow[t]{4}{*}{$\begin{array}{l}\text { Implementation/Development } \\
\text { phase }(2005-2006)\end{array}$} & $\begin{array}{l}\text { Oreng Jeppang ngajheg } \\
\text { jhujhur }\end{array}$ & $\begin{array}{l}\text { Japanese (company) } \\
\text { asks for honesty }\end{array}$ \\
\hline & & Oreng Islam pajhujhur & $\begin{array}{l}\text { Muslims are obliged } \\
\text { to be honest }\end{array}$ \\
\hline & & Pabenyak asokkor & $\begin{array}{l}\text { To be continuously to } \\
\text { thank God }\end{array}$ \\
\hline & & $\begin{array}{l}\text { Ajeg bheleh tanggeh } \\
\text { padheh jhujhur }\end{array}$ & $\begin{array}{l}\text { to persuade relatives } \\
\text { and neighbors to be } \\
\text { honest (the program) }\end{array}$ \\
\hline \multirow[t]{2}{*}{3} & \multirow{2}{*}{$\begin{array}{l}\text { Registration for International } \\
\text { ecolabel certification phase } \\
(2006-2007)\end{array}$} & Regghenah lebbi larang & $\begin{array}{l}\text { the price (of log) is } \\
\text { higher }\end{array}$ \\
\hline & & Dhulih ongghe hajji & $\begin{array}{l}\text { may go on pilgrim } \\
\text { soon }\end{array}$ \\
\hline
\end{tabular}


VOL. 01 NO. 01, JUNE 2019

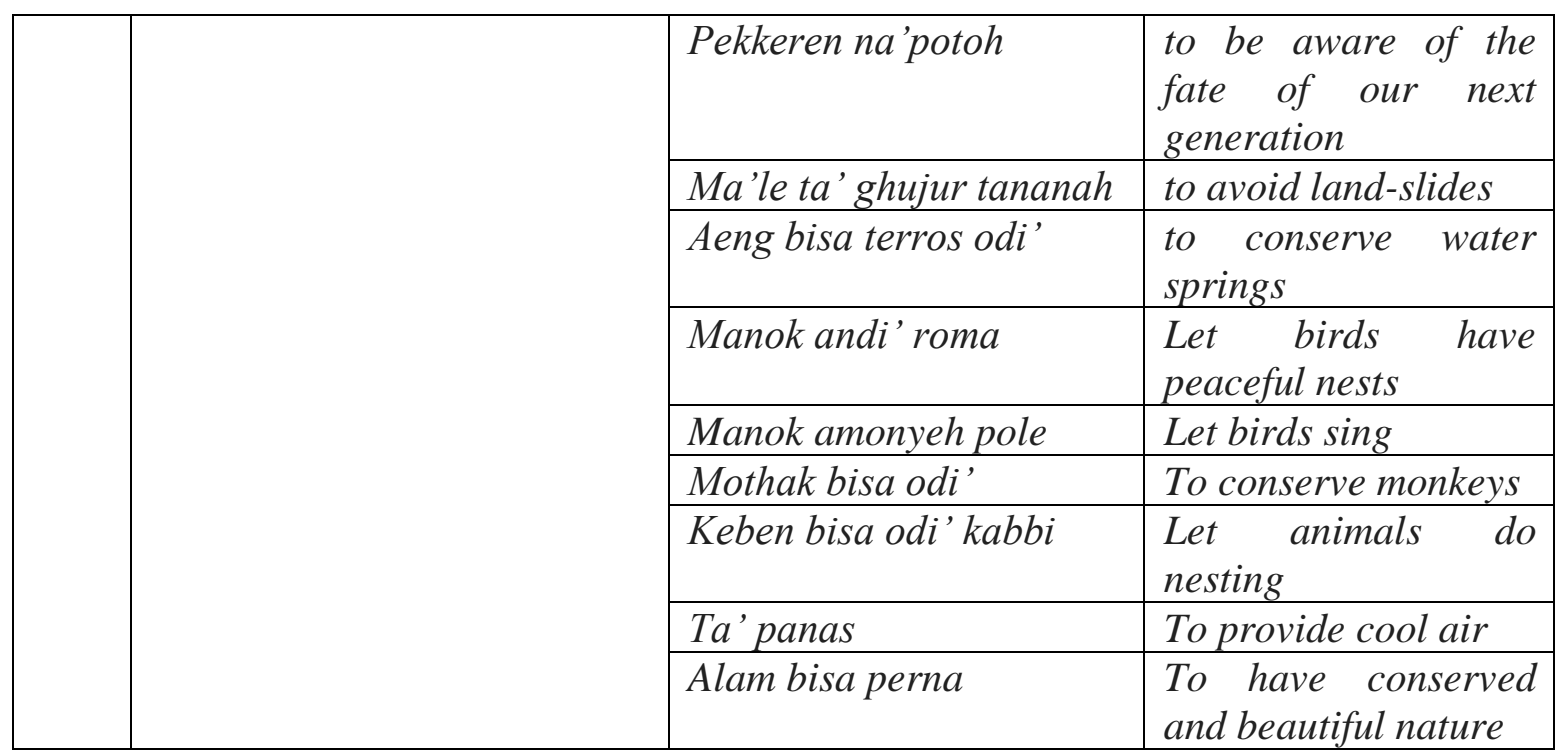

As presented above, dictions used by religious leaders are different in each stage. The dictions extend from words which emphasize on the importance of improving economic welfare to that of social sustainability, and natural preservation. In initiation phase of extension forestry program, for example, dictions on economical benefits that are potentially received are frequently used. Dictions on moral values, as the matter of fact, are more frequently used in development phase. The last, the dictions concerning natural preservation are mostly used at the last phase of the program, namely on international ecolabel certification phase.

Dictions classified as relative advantage of the program in terms of economic advantages and welfare are used frequently in initiation phase. Comparations and contrasts on advantages of lands: to be involved or to be left unplanted (tanembhang bendung sabenah) is an example. Through this diction, religious leader gives a clear explanation that nothing to loose from joining the program. Some benefits, in vise versa, will be got when they participate. The phrase of "to avoid endless poverty (ma'le ta' mesken salanjanga)" is one of representative example of this discussion. Other phrases that have the same tone to this explanation are: "to make motorcycle (and other tertiary needs) affordable", "compared to that of being coolies in Surabaya", "to be able to build house", "to be able to go on pilgrimage", and "to be able to pay for their children' tuition fee in higher education".

Furthermore, still in initiation phase, the religious leader also explored the compatibility of the program. In the condition that the land-owners were lack of money, religious leader assured the owners that they did not need to provide money for any costs. Religious leader stated that all costs would be paid by the religious leader as investor. By implementing this format, the land-owners are positioned in a nothing-to-loose relationship. The phrase of " $t a$ ' rogi napah" that means "nothing to loose", therefore, became popular in the community. The phrase was either used by religious leader to answer risks that might be faced if the community join the program or by land-owners when they explained to their family and relatives about the program.. The religious leader used this phrase with a brief assurance that the community were free from any costs needed during the planting up to the harvesting time. When the woods were harvested, in addition, the land-owners got their concession in the proportion of 50:50. Both parties called this proportion as "paroan" or "split half".

In other words, it can be noted that dictions of economic advantages and welfare are used to build trust in the community to join the program. The trust was built through two aspects, 


\section{VOL. 01 NO. 01, JUNE 2019}

namely land-owers' favor as orientation, and compatibility program in connection with landowners' weakness. Land-owners' favor as orientation was communicated by giving assurance that the advantages of the programs, especially in terms of economic advantages and welfare, are all in the favor of community. The compatibility of the program to the landowners' economic condition, in addition, was delivered by explaining that no costs are carried on to the land-owners. In the implementation of the program, as an additional information, all costs were borne by religious leader as investor. With these two characteristics, the religious leader found that rejections were absent in the initiation phase of the program. It means that understanding and persuasion have come into trust building. The community is ready to adopt the innovation.

In implementation/development phase, religious leader found problem on loyalty on commitment. Some land-owners were found deviated from codes of conduct signed in agreement documents. Instead of planting all plantlets recieved, for example, some landowners sold them violently to other parties. Responding this abuse, religious leader brought the such land-owners to consciouness that the misconduct was shameful. Phrase of "Japanese (company) asks for honesty" or in Madurese stated as "oreng Jeppang ngajheg jhujhur" was echoed to be consistently honest. Religious leader also emphasized the importance of being honest as one of values in Islam. An utterance of "Muslims are obliged to be honest" or "oreng Islam pajhujhur" was always resonanced. Furthermore, religious leader asked the community to be grateful by obeying the codes in the agreement. Some utterances, namely "Please, thank to God countiously" or "pabenyak asokkor" and "persuade relatives and neighbours to be honest" or "ajheg bheleh tanggeh jhujhur" were also echoed to maintain good relationship with Japanese company who took involved in the program.

In other words, in the period of implementation/development of extension forestry program utteramces mostly echoed are those exclamations with strong objective of maintaining good relationship with Japanese company who provided seedlings. The exclamations were aimed at avoiding disatisfaction from Japanese company due to dishonest acts of some land-owners. It means that in this period religious leader was busy of building land-owners characters to maintain the program. This field belongs to social sustainability, but economical sustaiability remains the ultimate goal.

The last, in the period of registration for international ecolabel certification (2006-2007), religious leader used utterances categorized as natural preservation, in one hand, and economic advantages and welfare dictions, on the other hand. Religious leader build conscionousness on the importance of natural preservation through utterances such as "pekkeren na' potoh" or "please, be aware of the our next generation's fate", "ta' panas" or "to provide cool air", "alam bisa perna" or "to have conserved and beautiful nature", "Keben bisa odi' kabbi" or "Let animals do nesting", "Mothak bisa odi" or "to conserve monkeys", "manok amonyeh pole" or "make birds sing", "manok andi' roma" or "Let birds have peaceful nests" , "Ma'le ta' ghujur tananah", or "to avoid land-slides". These exclamation, however, were used to strenghten the land-owners' commitment to join international ecolabel certification program. To attract the to join the such program, whereas, religious leader, again used economic relative advantages words. The phrase of "regghenah lebbi larang" or "the price (of $\log$ ) is higher was always used to convince them. Together with the phrase of "Dhulih ongghe hajji" or "may "go on pilgrim soon" religious leader promoted the international ecolabel registration program. And, it was mentioned many times, religious leader harvested success story in this phase.

\section{Conclusion and Proposition}

In conclusion, without any prejudice to come up with words that are intended to preserve ecological environment and social sustainability, the success story of extension forestry 


\section{VOL. 01 NO. 01, JUNE 2019}

program in rural setting in Probolinggo municipal is affected by dictions that are suitable to society's interests, namely relative economic advantages. Dictions of other fields are mostly functioned as reinforcement words or phrases. The proposition that is put forward from this study, therefore, is as the following:

"the communication of innovation, in this study is extension forestry program, will be able to be quickly and widely accepted by villagers if the dictions used are words categorized as economical benefits of the program"

\section{References}

Agus, Fahmudin, Noordwijk, Meine Van, Rahayu, Subekti. 2004. Dampak Hidrologis Hutan, Agroforestry, dan Pertanian Lahan Kering sebagai Dasar Pemberian Imbalan kepada Penghasil Jasa Lingkungan di Indonesia. Prosiding Lokakarya di Padang/Singkarak, Sumatra Barat, Indonesia 25-28 Pebruari 2004. Bogor: ICRAF

Anonymous. 2006. Sustaining Economic Growth, Rural Livelihoods, and Environmental Benefits: Strategic Options for Forest Sector Assistence in Indonesia (Draft). Washington DC: World Bank www.proquest.com/pqdweb. Dikunjungi tanggal 1 Oktober 2008

Carman, Peter JB. 2008. I was a stranger. The Christian Century. 125.25 (December 16, 2008): $12-13$

Geertz, Clifford. 1960. The Javanese Kijaji: The Changing Role of A Cultural Broker, In: Comparative Studies In Society And History, Vol. 2, No. 2 (Jan., 1960), 228-249.

Glendinning, Anthony, Mahapatra, Ajay, Mitchell, Paul. 2001. Modes of Communication and Effectiveness of Agroforestry Extension in Eastern India. Human Ecology. New York: Sep 2001. Vol. 29, Edisi 3; pg. 283, 23 pgs

Honig-Haftel, Sandra. 1996. The Art of Framing: Managing the Language of Leadership. The academy of management perspectives. 10.1. (February, 1996): 97.

Humphreys, J.H., Pryor, M.G., Haden, S.P., Oyler, J.D. 2009. The Leadership of Joseph R. Walker: Towards a Model of Socialized Charisma through Expert Power. Journal of Applied Management and Entrepreneurship. For Lauderdale. Volume 14. Edisi 1. www.proquest.com/pqdweb. Dikunjungi tanggal 10 Agustus 2009.

Kuttner, Robert. 2003. Language and Leadership. The American prospect. 14.8 (Septermber 2003):3

Levesque, Carl. 2004. The Language of Leadership. Association Management. 56.1. (Jan 2004):49-51.

Pittaway, Luke; Rivera, Olga; Murphy, Anne. 2005. Social Identity and Leadership in the Basque Region: a Study of Leadership Development Programmes. Journal of leadership and organizational studies: 11.3 (2005): 17-29

Rogers , Everett M. 1983. Diffusion of Innovations. New York: The Free Press, A Division of Macmillan Publishing Co., Inc.

Rogers, Everett M., Shoemaker, F. Floyd. 1971. Communication of Innovation. Second Edition. The Free Press. A Division of Macmillan Publishing Co., Inc.

Wejnert, Barbara. 2002. Integrating Models of Diffusion of Innovations: a Conceptual Framework. Annual Review of Sociology. 2002. 28. Academic Research Library. Pg. 297. www.proquest.com/pqdweb. Dikunjungi tanggal 18 September 2009

Wibowo, Soetino. 2006. Analisis Biaya Pembalakan. Bogor: Fakultas Kehutanan IPB 